\title{
Trends in body mass index in young adults in England and Scotland from 1973 to 1988
}

\author{
M C Gulliford, R J Rona, S Chinn
}

\begin{abstract}
Study objective-The aim was to determine whether the mean body mass index of young adults in England and Scotland had increased during the years 1973 to 1988 .

Design-The study was an analysis of reported heights and weights for parents of children participating in a mixed longitudinal study of children's growth.

Setting-20 study areas (16 in England and four in Scotland) were selected by stratified random sampling.

Subjects-Subjects were parents of 5229 children who were new entrants to the study in the years 1973-6 and 1982-8. After excluding cases containing missing values on continuous variables, data for $4568(87 \%)$ women (mean age 30 years) and $4029(77 \%)$ men (mean age approximately 32 years) were analysed.
\end{abstract}

Measurements and main resultsChanges in weight for height over time were determined using body mass index as dependent variable, adjusting for age, social class, family size, and study area. In women, mean body mass index showed an annual increase of $0.10(95 \%$ CI 0.03 to $0.17 \%)$ per year of study. Body mass index also increased with increasing age and family size and was greatest for women with husbands in manual occupations. The secular trend in body mass index in women was not explained by changes in the distribution of these variables. The proportion of women with BMI $>25 \mathrm{~kg} / \mathrm{m}^{2}$ increased over the study period. In men the secular trend in body mass index was not quite significant in this age group [annual increase $0.05 \%(-0.01$ to $0 \cdot 12 \%)]$.

Conclusions-There has been an increase in the body mass index of young women in England and Scotland over the years 1973 to 1988. This increase was not explained by changes in the age, parity, social class of the subjects sampled. Evidence of a trend in men was not found.

Obesity is an important but poorly defined public health problem in the United Kingdom. ${ }^{12}$ The absence of detailed information concerning the distribution of overweight and obesity in the UK population led to the commissioning of a national survey of the heights and weights of adults in Great Britain. ${ }^{34}$ These data, recorded in 1980, showed that at ages of 30 to 34 years, $34 \%$ of men were overweight, with body mass index (BMI)
$>25 \mathrm{~kg} / \mathrm{m}^{2}$, and $6 \%$ were obese (BMI $>30 \mathrm{~kg} / \mathrm{m}^{2}$ ). The proportions of women falling into the same categories were $22 \%$ and $4 \%$ respectively. In the absence of continuing surveillance of the adult population there is only limited evidence to show whether the proportion of obese individuals is changing over time in the United Kingdom.

The National Study of Health and Growth (NSHG) is a surveillance study of primary school children living in England and Scotland, which has been conducted annually since 1972 . In most years the parents of children participating in the study have been asked to record their own heights and weights. The validity of self-reported heights and weights has been well documented. ${ }^{5-9}$ This analysis aimed to determine whether there has been a secular trend in body mass index in the parents of these children.

\section{Methods}

SUBJECTS

The study areas of the NSHG were selected by stratified random sampling from the employment exchange areas in England and Scotland. ${ }^{10}$ The sampling was weighted to give greater representation to poorer areas ${ }^{10}$ but the social class characteristics of the children in the study were similar to those of the general population. ${ }^{11}$ Within the 22 areas in England and six in Scotland, schools were chosen by the education authority and all of the children in the school participated in the study. The heights, weights, and skinfold thickness measurements of the chidren were measured and the parent or guardian completed a questionnaire. Six of the English areas and two of the Scottish areas have been replaced by areas in the same original stratum during the course of the study. The remaining areas have participated in the study in all years. In five areas the participating school has changed and in one area an additional school was recruited because of falling school rolls, but replacement schools have been similar in character to their predecessors.

Relationships between siblings taking part in the study are not routinely recorded so that repeated responses by the same parents of different children cannot be identified directly. In order to avoid including repeated observations from the same parents, cases were selected in which the child was a new entrant to the study and had no older siblings. In 1972, the first year of the study, all of the children were new entrants, so data from this year were omitted in order to avoid overrepresentation. Parental heights but not weights were recorded in the years 1977-1981. 
The study areas have been visited in alternate years since 1982. Cases were therefore selected from the years 1973-6 inclusive and 1982, 1984, 1986 , and 1988.

Table I Mean values for age, height, weight, and body mass index (BMI) by husband's social class and time period for women. Figures are: mean ( $95 \%$ range) for height; geometric mean (95\% range) for age, weight and BMI; proportion with $B M I \geqslant 25 \mathrm{~kg} / \mathrm{m}^{2}$ as percentage ( $95 \%$ confidence interval)

\begin{tabular}{|c|c|c|}
\hline Social class & $1973-6$ & $1982-8$ \\
\hline $\begin{array}{l}\text { Non-manual } \\
\text { Number } \\
\text { Age (years) } \\
\text { Height }(\mathrm{cm}) \\
\text { Weight }(\mathrm{kg}) \\
\text { BMI }\left(\mathrm{kg} / \mathrm{m}^{2}\right) \\
\text { BMI } \geqslant 25 \mathrm{~kg} / \mathrm{m}^{2}(\%)\end{array}$ & $\begin{array}{ll}638 & \\
30 \cdot 8 & (23 \cdot 7-40 \cdot 1) \\
162 \cdot 5 & (149 \cdot 7-175 \cdot 3) \\
58 \cdot 56 & (45 \cdot 33-75 \cdot 64) \\
22 \cdot 28 & (17 \cdot 74-27 \cdot 77) \\
13 \cdot 7 & (11 \cdot 0-16 \cdot 4)\end{array}$ & $\begin{array}{ll}956 & \\
32 \cdot 9 & (25 \cdot 6-42 \cdot 1) \\
162 \cdot 8 & (150 \cdot 4-175 \cdot 2) \\
59 \cdot 03 & (44 \cdot 70-77 \cdot 94) \\
22 \cdot 30 & (17 \cdot 25-28 \cdot 56) \\
15 \cdot 4 & (13 \cdot 1-17 \cdot 7)\end{array}$ \\
\hline $\begin{array}{l}\text { Skilled manual } \\
\text { Number } \\
\text { Age (years) } \\
\text { Height }(\mathrm{cm}) \\
\text { Weight }(\mathrm{kg}) \\
\text { BMI }\left(\mathrm{kg} / \mathrm{m}^{2}\right) \\
\text { BMI } \geqslant 25 \mathrm{~kg} / \mathrm{m}^{2}(\%)\end{array}$ & $\begin{array}{cl}671 & \\
28 \cdot 7 & (21 \cdot 8-37 \cdot 7) \\
161 \cdot 4 & (148 \cdot 6-174 \cdot 2) \\
58 \cdot 56 & (43 \cdot 73-78 \cdot 41) \\
22 \cdot 56 & (17 \cdot 46-29 \cdot 37) \\
18 \cdot 2 & (15 \cdot 2-21 \cdot 2)\end{array}$ & $\begin{array}{cl}876 & \\
29 \cdot 9 & (22 \cdot 6-39 \cdot 7) \\
161.9 & (148 \cdot 7-175 \cdot 1) \\
59 \cdot 80 & (42 \cdot 78-83 \cdot 10) \\
22 \cdot 87 & (16 \cdot 91-30 \cdot 94) \\
22 \cdot 7 & (19 \cdot 9-25 \cdot 5)\end{array}$ \\
\hline $\begin{array}{l}\text { Semi and unskilled manu } \\
\text { Number } \\
\text { Age (years) } \\
\text { Height }(\mathrm{cm}) \\
\text { Weight }(\mathrm{kg}) \\
\text { BMI }\left(\mathrm{kg} / \mathrm{m}^{2}\right) \\
\text { BMI } \geqslant 25 \mathrm{~kg} / \mathrm{m}^{2}(\%)\end{array}$ & $\begin{array}{cl}267 & \\
28 \cdot 5 & (20 \cdot 5-39 \cdot 6) \\
161.6 & (147 \cdot 4-175 \cdot 8) \\
60 \cdot 10 & (44 \cdot 08-81 \cdot 94) \\
23.06 & (17 \cdot 46-30 \cdot 57) \\
24.7 & (19 \cdot 4-30 \cdot 0)\end{array}$ & $\begin{array}{cl}333 & \\
28 \cdot 6 & (21 \cdot 0-39 \cdot 0) \\
161 \cdot 5 & (148 \cdot 5-174 \cdot 5) \\
61 \cdot 31 & (41 \cdot 93-89 \cdot 66) \\
23 \cdot 54 & (16 \cdot 61-33 \cdot 45) \\
28 \cdot 2 & (23 \cdot 3-33 \cdot 1)\end{array}$ \\
\hline $\begin{array}{l}\text { Unclassified } \\
\text { Number } \\
\text { Age (years) } \\
\text { Height }(\mathrm{cm}) \\
\text { Weight }(\mathrm{kg}) \\
\text { BMI }\left(\mathrm{kg} / \mathrm{m}^{2}\right) \\
\text { BMI } \geqslant 25 \mathrm{~kg} / \mathrm{m}^{2}(\%)\end{array}$ & $\begin{array}{cl}335 & \\
29 \cdot 2 & (21 \cdot 2-40 \cdot 0) \\
161 \cdot 6 & (148 \cdot 2-175 \cdot 0) \\
57 \cdot 80 & (43 \cdot 16-77 \cdot 4) \\
22 \cdot 20 & (17 \cdot 05-28 \cdot 90) \\
15 \cdot 5 & (11 \cdot 6-19 \cdot 5)\end{array}$ & $\begin{array}{cl}492 & \\
29 \cdot 0 & (21 \cdot 0-40 \cdot 0) \\
162 \cdot 2 & (147 \cdot 4-177 \cdot 0) \\
59.50 & (43 \cdot 47-81 \cdot 29) \\
22 \cdot 65 & (16 \cdot 88-30 \cdot 39) \\
19 \cdot 7 & (16 \cdot 1-23 \cdot 3)\end{array}$ \\
\hline
\end{tabular}

Table II Mean values for age, height, weight, and body mass index (BMI) by social class and time period for men. Figures as table I

\begin{tabular}{|c|c|c|}
\hline Social class & $1973-6$ & $1982-8$ \\
\hline $\begin{array}{l}\text { Non-manual } \\
\text { Number } \\
\text { Age (years) } \\
\text { Height }(\mathrm{m}) \\
\text { Weight }(\mathbf{k g}) \\
\text { BMI }\left(\mathrm{kg} / \mathrm{m}^{2}\right) \\
\text { BMI } \geqslant 25 \mathrm{~kg} / \mathrm{m}^{2}(\%)\end{array}$ & $\begin{array}{cl}603 & \\
33 \cdot 0 & (24 \cdot 7-44 \cdot 2) \\
177 \cdot 5 & (163 \cdot 9-191 \cdot 1) \\
74.96 & (57 \cdot 00-98 \cdot 59) \\
23.81 & (18 \cdot 88-30 \cdot 02) \\
30 \cdot 7 & (26 \cdot 9-34 \cdot 5)\end{array}$ & $\begin{array}{ll}918 & \\
- & \\
178 \cdot 0 & (164 \cdot 4-191 \cdot 6) \\
75 \cdot 57 & (58 \cdot 62-97 \cdot 42) \\
23.89 & (19 \cdot 18-29 \cdot 55) \\
31 \cdot 4 & (28 \cdot 3-34 \cdot 5)\end{array}$ \\
\hline $\begin{array}{l}\text { Skilled manual } \\
\text { Number } \\
\text { Age (years) } \\
\text { Height }(\mathrm{cm}) \\
\text { Weight }(\mathrm{kg}) \\
\text { BMI }\left(\mathrm{kg} / \mathrm{m}^{2}\right) \\
\text { BMI } \geqslant 25 \mathrm{~kg} / \mathrm{m}^{2}(\%)\end{array}$ & $\begin{array}{cl}639 & \\
31 \cdot 0 & (23 \cdot 4-41 \cdot 2) \\
175 \cdot 7 & (162 \cdot 5-188 \cdot 9) \\
74 \cdot 29 & (57 \cdot 28-96 \cdot 35) \\
24 \cdot 10 & (19 \cdot 14-30 \cdot 20) \\
38 \cdot 7 & (34 \cdot 9-42 \cdot 6)\end{array}$ & $\begin{array}{ll}793 & \\
\overline{176 \cdot 7} & (162 \cdot 3-191 \cdot 1) \\
75 \cdot 94 & (58 \cdot 21-98 \cdot 59) \\
24 \cdot 26 & (19 \cdot 18-30 \cdot 75) \\
36.6 & (33 \cdot 2-40 \cdot 0)\end{array}$ \\
\hline $\begin{array}{l}\text { Semi-skilled and unskille } \\
\text { Number } \\
\text { Age (years) } \\
\text { Height }(\mathrm{cm}) \\
\text { Weight }(\mathrm{kg}) \\
\text { BMI }\left(\mathrm{kg} / \mathrm{m}^{2}\right) \\
\text { BMI } \geqslant 25 \mathrm{~kg} / \mathrm{m}^{2}(\%)\end{array}$ & $\begin{array}{ll}\text { ual } & \\
255 & \\
31 \cdot 0 & (22 \cdot 4-42 \cdot 9) \\
174 \cdot 6 & (170 \cdot 6-188 \cdot 6) \\
72.97 & (55 \cdot 92-95 \cdot 58) \\
24 \cdot 02 & (19 \cdot 03-30 \cdot 39) \\
36.5 & (30 \cdot 5-42 \cdot 5)\end{array}$ & $\begin{array}{l}310 \\
-\quad \\
175 \cdot 0(160 \cdot 2-189 \cdot 8) \\
74 \cdot 14 \quad(55 \cdot 59-98 \cdot 89) \\
24 \cdot 24 \quad(19 \cdot 03-31 \cdot 00) \\
40 \cdot 6 \quad(35 \cdot 0-46 \cdot 2)\end{array}$ \\
\hline $\begin{array}{l}\text { Unclassified } \\
\text { Number } \\
\text { Age (years) } \\
\text { Height (m) } \\
\text { Weight }(\mathbf{k g}) \\
\text { BMI }\left(\mathbf{k g} / \mathrm{m}^{2}\right) \\
\text { BMI } \geqslant 25 \mathrm{~kg} / \mathrm{m}^{2}(\%)\end{array}$ & $\begin{array}{cl}192 & \\
32 \cdot 0 & (22 \cdot 0-46 \cdot 3) \\
176 \cdot 9 & (163 \cdot 7-190 \cdot 1) \\
73 \cdot 77 & (56 \cdot 26-96 \cdot 54) \\
23 \cdot 62 & (18 \cdot 77-29 \cdot 61) \\
31 \cdot 8 & (25 \cdot 1-38 \cdot 5)\end{array}$ & $\begin{array}{ll}319 & \\
- & \\
176 \cdot 1 & (161 \cdot 9-190 \cdot 3) \\
73 \cdot 70 & (55 \cdot 92-97 \cdot 13) \\
23 \cdot 71 & (18 \cdot 73-30 \cdot 27) \\
28 \cdot 8 & (23 \cdot 7-33 \cdot 9)\end{array}$ \\
\hline
\end{tabular}

Table III Body mass index by educational attainment for men and women. Figures are: number in category; geometric mean body mass index (BMI) (95\% range)

\begin{tabular}{|c|c|c|c|c|}
\hline \multirow{2}{*}{$\begin{array}{l}\text { Level of } \\
\text { education }\end{array}$} & \multicolumn{2}{|l|}{ Men } & \multicolumn{2}{|c|}{ Women } \\
\hline & $n$ & $B M I$ (95\% range) & $n$ & $B M I$ (95\% range) \\
\hline $\begin{array}{l}\text { Primary/secondary } \\
\text { Commercial/technical } \\
\text { University/polytechnic } \\
\text { None/not known }\end{array}$ & $\begin{array}{r}1160 \\
267 \\
214 \\
2388 \\
\end{array}$ & $\begin{array}{l}23.92(19 \cdot 01-30.09) \\
23.95(19 \cdot 25-29.81) \\
23.80(19 \cdot 20-29 \cdot 51) \\
24.05(19 \cdot 19-30 \cdot 14) \\
\end{array}$ & $\begin{array}{r}3143 \\
894 \\
475 \\
56 \\
\end{array}$ & $\begin{array}{l}22 \cdot 71(17 \cdot 17-30 \cdot 05) \\
22 \cdot 43(17 \cdot 39-28.93) \\
22 \cdot 25(17 \cdot 39-28 \cdot 47) \\
22 \cdot 46(17 \cdot 34-29.08)\end{array}$ \\
\hline
\end{tabular}

DEFINITION OF VARIABLES

In the years 1973 to 1976 the questionnaire included the following questions: "Please answer the following questions about yourself: How tall are you (without shoes)? How much do you weigh? If you are married, please answer the following questions about your husband or wife: What is his or her height (without shoes)? How much does he or she weigh?" In the years 1982 to 1988 the respondent completed the following questions: "How tall is this child's natural mother? How much does she weigh? How tall is this child's natural father? How much does he weigh?" The relationship of the questionnaire respondent to the child was recorded in all years. Responses for height and weight were requested in feet and inches and in stones and pounds respectively. These measures were converted to centimetres and kilograms. The questionnaire also requested information concerning the social background of the family and included questions concerning the education and employment of the parents and the number of children in the family. The year of birth of the mother was recorded in all years and was used to calculate women's ages. The year of birth of the father was available only for the years 1973-6. The social class of men was defined according to the Registrar General's classification but was reduced to the following categories: non-manual occupation; skilled manual; semiskilled and unskilled manual; unclassified. Women were classified according to the social class of the husband. The number of children in the family was categorised as: one; two; three; four or more; not known. The educational attainment of the parents was classified as: primary or secondary; commercial or technical; university or polytechnic; no school education or not known.

\section{ANALYSIS}

Cases containing missing values on height, weight, or age were excluded from analysis. Values for height were normally distributed and were represented as the mean and $95 \%$ range ( \pm 2 SD). The distributions of age, weight, and body mass index were positively skewed in both sexes but the logarithms of these variables were approximately normally distributed. The antilog of the mean of the log transformed variable $( \pm 2 \mathrm{SD})$ gave the geometric mean ( $95 \%$ range). After showing that changes over time were adequately described as a linear trend, the association of $\log$ body mass index with year of study was examined using linear regression. The year of study was entered as a quantitative variable; 1972 was the first year of the study, the years 1973 to 1988 were thus years 2 to 17 of the study. Multiple regression was used to adjust for the associations of other explanatory variables with body mass index.

\section{Results}

The selection procedure identified 7662 children (mean maternal BMI $22.53 \mathrm{~kg} / \mathrm{m}^{2}$, paternal BMI $23.98 \mathrm{~kg} / \mathrm{m}^{2}$ ) fulfilling the inclusion criteria. Initial analyses showed that variation in body mass index between study areas was significant. Subsequent analyses were therefore confined to 
the data reported from parents of 5229 children who were resident in areas (16 in England and four in Scotland) which had participated in the study in all years. After excluding cases containing missing values, data for $4568(87 \%)$ women (mean BMI $22.61 \mathrm{~kg} / \mathrm{m}^{2}$ ) and $4029(77 \%)$ men (mean BMI $23.99 \mathrm{~kg} / \mathrm{m}^{2}$ ) were available for analysis.

Mean values for age, height, weight, and body mass index for the time periods 1973-6 and 1982-8 are presented, by social class, in tables I and II. In women, body mass index showed a gradient with social class being greatest for women with husbands in semiskilled and unskilled manual occupations (table I). There was an increase in mean body mass index between the two time periods which appeared to be confined to women with husbands in manual occupations. The overall increase in the proportion of women with body mass index greater than $25 \mathrm{~kg} / \mathrm{m}^{2}$ between the two time periods was $3.1 \%(95 \% \mathrm{CI}$ 0.8 to $5.4 \%)$. The increase was $4.2 \%(0.6$ to $7 \cdot 8 \%$ ) for women with husbands in manual occupations compared with $1.6 \%(-2.0$ to $5.1 \%)$ for women with husbands in non-manual occupations. In men (table II) the increase in the proportion of men with body mass index greater than $25 \mathrm{~kg} / \mathrm{m}^{2}$ between the two time periods was not significant, with an increase of $0.3 \%(-2.6$ to $3.3 \%)$. Body mass index was negatively associated with educational attainment in men and women (table III). However, educational attainment accounted for a smaller proportion of explained variation in

Table IV Associations of In body mass index and explanatory variables in women. Figures are coefficients (SE) for continuous variables and the mean difference ( $S E$ ) from the last mentioned category for categorical variables; each is adjusted for the other variables

\begin{tabular}{llcc}
\hline Independent variable & Coefficient $(S E)$ & F ratio & $p$ value \\
\hline $\begin{array}{l}\text { Univariate regression } \\
\text { Intercept }\end{array}$ & $3.108(0.004)$ & & \\
Year of study & $0.00099(0.00036)$ & 7.72 & 0.006 \\
Multiple regression & & & \\
Intercept & $3.042(0.030)$ & & \\
Year of study & $0.00092(0.00036)$ & 6.33 & 0.012 \\
Age (years) & $0.0015(0.0004)$ & 10.69 & 0.001 \\
Number of children & $0.0174(0.0261)$ & 2.41 & 0.047 \\
1 & $0.0215(0.0258)$ & & \\
2 & $0.0348(0.0262)$ & & \\
3 & $0.0420(0.0288)$ & & \\
$4+$ & 0.0 & 16.14 & $<0.001$ \\
$\quad$ Not known & $0.0094(0.0062)$ & & \\
Husband's social class & $0.0107(0.0060)$ & & \\
$\quad$ Non-manual & $0.0366(0.0075)$ & & \\
Skilled manual & 0.0 & \\
$\quad$ Semi- and unskilled manual & 20 levels not shown & 1.65 & 0.038 \\
$\quad$ Not known & & & \\
Study area & &
\end{tabular}

Table $V$ Associations of explanatory variables and ln body mas index in men. Figures as in table IV

\begin{tabular}{|c|c|c|c|}
\hline Independent variable & Coefficient (SE) & $F$ ratio & $p$ value \\
\hline $\begin{array}{l}\text { Univariate regression } \\
\text { Intercept } \\
\text { Year of study }\end{array}$ & $\begin{array}{l}3.172 \quad(0.004) \\
0.00053(0.00032)\end{array}$ & $2 \cdot 76$ & 0.097 \\
\hline $\begin{array}{l}\text { Multiple regression } \\
\text { Intercept } \\
\text { Year of study } \\
\text { Social class } \\
\text { Non-manual } \\
\text { Skilled manual } \\
\text { Semi- and unskilled manual } \\
\text { Not known } \\
\text { Study area } \\
\text { Residual mean square } 0.013 \text { df } 4005\end{array}$ & $\begin{array}{l}3.161 \quad(0.010) \\
0.00048(0.00032) \\
0.0070(0.0060) \\
0.0208(0.0060) \\
0.0186(0.0071) \\
0.0000 \quad \\
20 \text { levels not shown }\end{array}$ & $\begin{array}{l}2 \cdot 29 \\
5 \cdot 96\end{array}$ & $\begin{array}{r}0.131 \\
<0.001\end{array}$ \\
\hline
\end{tabular}

body mass index than did social class, and maternal educational attainment was not independently associated with body mass index after adjusting for social class in multiple regression analyses.

Univariate linear regression showed that log body mass index was positively associated with the year of study in women (table IV) but in men (table V) the trend was not significant. Transformation of the coefficients showed that mean body mass index increased by $0 \cdot 10^{\circ}{ }_{0}\left(95^{\circ}{ }_{0} \mathrm{CI}\right.$ 0.03 to $0.17^{\circ}$ ) per year in women and $0.05^{\circ}$ \% $(-0.01$ to $0.12 \%)$ per year in men. It was necessary to evaluate whether these estimates were accounted for by changes in age and socioeconomic status over the period of investigation. In women, adjustment was made for age, number of children (as a measure of parity), husband's social class, and study area. In men, adjustment was made for study area and social class, the age of male subjects not being recorded in all years. Adjusting for these variables produced little change in the magnitude of the regression coefficient of body mass index on year of study either in women (table IV) or men (table V). Where available for analysis, the age of men was strongly associated with the age of their wives $(\mathrm{r}=0.76)$. If additional adjustment was made for the wife's age then the regression of log body mass index on year of study for men was approximately zero: coefficient (SE) 0.0001 (0.0003). The slight trend towards increasing body mass index in men might have been accounted for by an increase in the mean age of the subjects sampled. The first order interaction between year of study and social class was not significant either for men or women.

\section{Discussion}

The data presented show that there has been a significant increase in body mass index for women aged approximately 20 to 40 years between 1973 and 1988. This increase was not accounted for by changes in the age, parity, or social class of women participating in the study over this time period. A trend in body mass index in men was not found.

The subjects whose data are reported were sampled for the study as parents of primary school children. As such they may not be entirely representative of the adult population and some characteristics of individuals having children may have changed over time. However, the values of body mass index and their associations with social class are similar to those reported by the population based OPCS survey ${ }^{3} 4$ and Braddon $e t$ al. ${ }^{14}$ In the general population there has been an increase in maternal age ${ }^{1213}$ but this was a characteristic for which adjustment was made in the analysis.

The validity of self reported heights and weights has been well investigated. ${ }^{5-9}$ It has been shown that there is a slight bias in favour of the overestimation of height and the underestimation of weight. This will result in slight underestimation of the body mass index. This bias will not influence the assessment of temporal trends as long as there is no secular change in the validity of reporting. Over the time period investigated, there has been a slight change in the wording of the questions included in the study questionnaire, 
but the findings we have reported are consistent across all the years investigated.

We have not examined in detail the trend in the proportion of obese subjects but the increase in mean body mass index is consistent with an increasing proportion of obese individuals. Such an increase was shown for women on comparing the early and later years of the study. The proportion of obese individuals increases steeply with age both in men and women. ${ }^{15}$ If the trend towards increasing obesity in these cohorts of young women is carried forward into later life, a substantial increase in the prevalence of obesity could be anticipated. This trend also appears likely to increase the gradient in body mass index between non-manual and manual social classes.

The Dietary and Nutritional Survey of British Adults ${ }^{16}$ has recently reported data for a sample of 2197 men and women aged 16 to 64 years measured in 1986 and 1987. A comparison of these data with the results obtained by $\mathrm{Knight}^{4} \mathrm{six}$ years earlier provides additional evidence for an increase in body mass index in the British population, which is greater for women than men. Data from the National Health and Nutrition Examination Surveys in the United States also show a trend towards increasing body mass index for women aged 18 to 34 years between 1960 and $1980 .{ }^{17}$ Although this increase was present at all levels of income and education it was greatest for women with the lowest levels of education. Our data do not show a significant trend in body mass index for men. This finding is consistent with the results of other surveys of younger men. ${ }^{18} 19$ There is evidence of a trend towards increasing body mass index in older men from several studies which have investigated risk factors for coronary heart disease and their trends over time. ${ }^{20-23}$ One interpretation of these findings would be that environmental influences on obesity, ${ }^{24}$ which are likely to be responsible for a secular trend, have their effect at a later age in men than women. The general increase in obesity is in contrast to the decline in the prevalence of other recorded risk factors for coronary heart disease. ${ }^{25}$

This analysis provides evidence that the average body mass index is increasing among young women in England and Scotland. This trend will result in an increasing proportion of obese individuals, an effect which is likely to increase as these subjects reach older ages. A similar trend in men was not identified.

We thank the parents and children who have participated in the National Study of Health and Growth and all of our colleagues in the study areas and at the St Thomas's Campus of the United Medical and Dental Schools who have participated in the work of the study. We are indebted to Professor W W Holland for his continued support and encouragement. The National Study of Health and Growth is supported by the Department of Health and the Scottish Home and Health Department. MCG was supported by the Wellcome Trust.

1 James WPT. Research on obesity. A report of the DHSS/ $M R C$ group. London: HMSO, 1976.

2 Royal College of Physicians. Obesity report. $f R$ Coll Physicians Lond 1983; 17: 5-65.

3 Rosenbaum S, Skinner RK, Knight IB, Garrow JS. A survey of heights and weights of adults in Great Britain. Ann Hum Biol 1985; 12: 115-27.

$4 \mathrm{Knight}$ I. The heights and weights of adults in Great Britain. London: Office of Population Censuses and Surveys, HMSO, 1984.

5 Altman D, Irwig L. Men, women and obesity. BM7 1975; i: 573-4

6 Rona RJ, Morris RW. National Study of Health and Growth: social and family factors and overweight in English and Scottish parents. Ann Hum Biol 1982; 9: 147-56.

7 Millar WJ. Distribution of body weight and height: comparison of estimates based on self-reported and observed measures. $\mathcal{F}$ Epidemiol Community Health 1986; 40: $319-23$.

8 Palta M, Prineas RJ, Berman R, Hannan P. Comparison of self-reported and measured height and weight. $A m \mathcal{f}$ Epidemiol 1982; 115: 223-30.

Epidemiol 1982; 115: 223-30.

Stewart AW, Jackson RT, Ford MA, Beaglehole R Underestimation of relative weight by use of self-reporte height and weight. Am $\mathcal{F}$ Epidemiol 1987; 125: 122-6.

10 Irwig LM. Surveillance in developed countries with particular reference to child growth. Int $\mathcal{F}$ Epidemiol 1976; 5: $57-61$

11 Rona RJ, Altman DG. National Study of Health and Growth: standards of attained height, weight and triceps skinfold in English children 5 to 11 years old. Ann Hum Biol 1977; 4: 501-23.

12 Central Statistical Office. Social Trends 20. London: HMSO, 1990.

13 Werner B. Family size and age at birth: trends and projections. Popul Trends 1982; 33: 4-13.

14 Braddon FEM, Rodgers B, Wadsworth MEJ, Davies JMC Onset of obesity in a thirty six year birth cohort. $B M F 1986$ 293: 299-303.

15 Millar WJ, Stephens T. The prevalence of overweight and obesity in Britain, Canada and the United States. Am $\mathcal{F}$ Public Health 1987; 77: 38-41.

16 Gregory J, Foster K, Tyler H, Wiseman M. The dietary and nutritional survey of British adults. London: Office of nutritional survey of British adults. London: Offic

17 Flegal KM, Harlan WR, Landis JR. Secular trends in body mass index and skinfold thickness with socioeconomic factors in young adult women. Am $\mathfrak{f}$ Clin Nutr 1988; 48: f35-43.

18 Flegal KM, Harlan WR, Landis JR. Secular trends in body mass index and skinfold thickness with socioeconomic factors in young adult men. Am f Clin Nutr 1988; 48 544-51.

19 Christensen U, Sonne-Holm S, Sorensen TIA. Constan median body mass index of Danish young men 1943-1977. Hum Biol 1981; 53: 403-10.

20 D'Agostino RB, Kannel WB, Belanger AJ, Sytowski PA. Trend in CHD and risk factors at age 55-64 in the Framingham study. Int $\mathcal{f}$ Epidemiol 1989; 18 (suppl 1) S67-72.

21 Burke GL, Sprafka HM, Folsom AR, Luepker RV, Norsted SW, Blackburn H. Trends in CHD mortality, morbidity and risk factor levels from 1960 to 1986: Minnesota Heart Survey. Int $\mathcal{f}$ Epidemiol 1989; 18 (suppl 1): S73-81.

22 Jamrozik $\mathrm{K}$, Hockey $\mathrm{R}$. Trends in risk factors for vascular disease in Australia. Med f Aust 1989; 150: 14-18.

23 Wilhelmsen L, Johansson S, Ulvenstam G, et al. CHD in Sweden: mortality, incidence and risk factors over twenty years in Gothenberg. Int $\mathcal{J}$ Epidemiol 1989; 18 (suppl 1): years in

24 Teasdale TW, Sorensen TIA, Stunkard AJ. Genetic and early environmental components in sociodemographic influences on adult body fatness. BMf $1990 ; 300: 1615-18$.

25 Blackburn $\mathrm{H}$. Trends and determinants of CHD mortality: changes to risk factors and their effects. Int $\mathcal{F}$ Epidemiol 1989; 18 (suppl 1): S210-15. 